\title{
Faktor Risiko pada Pasien Preeklampsia
}

\author{
Ratnawati $^{*}$, Yati Afiyanti ${ }^{2}$, Imami Nur Rachmawati ${ }^{3}$ \\ 1. Sekolah Tinggi Ilmu Kesehatan Muhammadiyah Pekajangan Pekalongan \\ *Email :Ratnawati2704@gmail.com \\ 2,3 Departemen Keperawatan Maternitas, Fakultas Ilmu Keperawatan Universitas \\ Indonesia, Kampus FIK UI, Jln. Prof. Dr. Bahder Djohan, Depok Jawa Barat 16424
}

\begin{abstract}
Abstrak. Angka kematian ibu di Indonesia pada tahun 2013 sebesar 190/100.000 kelahiran hidup. Penyebab kematian ibu sebagian besar karena preeklampsia. Pentingnya mengetahui faktor risiko preeklampsia agar dapat mencegah terjadinya peningkatan angka kematian ibu. Penelitian ini dilakukan untuk mengetahui faktor risiko pada pasien preeklampsia. Penelitian deskriptif ini meneliti faktor - faktor risiko pada 107 ibu preeklampsia di ruang postpartum RSUD Kraton, Kajen dan RSI Muhammadiyah Pekajangan, Kabupaten Pekalongan. Data yang diberikan adalah biodata responden dan kuesioner Status Sosial Ekonomi dengan analisa menggunakan software komputer. Preeclampsia terjadi pada ibu primipara sebanyak $51,4 \%$. berusia kurang dari atau sama dengan 35 tahun sebanyak $77,6 \% .57 \%$ pasien gemuk. Pasien preeklampsia tidak memiliki riwayat preeklampsia sebelumnya sebanyak $(95,3 \%)$ dan tidak memiliki riwayat penyakit kronis $79,4 \%$ dengan status sosial ekonomi sebanyak 77,6\% merupakan kelas menengah ke bawah. Pelayanan kesehatan perlu memperhatikan faktor-faktor risiko preeklampsia pada ibu hamil sehingga dapat mendeteksi lebih dini dan mendapat perawatan yang terkendali.
\end{abstract}

Kata Kunci :preeklampsia, status sosial ekonomi, faktor risiko

\section{Pendahuluan}

Angka kematian ibu di seluruh dunia pada tahun 2013 adalah sebesar 210/100.000 kelahiran hidup. Angka ini relatif turun $45 \%$ apabila dibandingkan dengan angka kematian ibu pada tahun 1990 yang sebesar 380/100.000 kelahiran hidup. (WHO, 2013). Angka kematian ibu di Indonesia pada tahun 2013 sebesar 190/100.000 kelahiran hidup. (WHO, 2013). Jumlah ini relatif menurun apabila dibandingkan tahun 2012 sebesar 359/100.000 kelahiran hidup. Namun demikian, angka ini masih tinggi apabila dibandingkan dengan target capaian MDGs sebesar 102/100.000 kelahiran hidup.

Angka kematian ibu disebabkan oleh perdarahan, hipertensi dalam kehamilan, infeksi, partus lama/macet, dan abortus. Pada tahun 2010, angka kematian ibu di Indonesia tertinggi disebabkan oleh hipertensi dalam kehamilan sebanyak $32 \%$, $31 \%$ dikarenakan komplikasi purperium, $20 \%$ karena perdarahan. (Kemenkes, 2014a). Data situasi kesehatan ibu dari Kemenkes, (2014) menggambarkan angka kematian ibu karena hipertensi dalam kehamilan pada tahun 2010 sebesar $21,5 \%$ dan pada tahun 2013 menjadi 27,1\% menunjukan terjadi peningkatan sebesar $5,6 \%$.

Penelitian Larrañaga et al., menunjukan bahwa ibu hamil dengan tingkat sosial ekonomi yang lebih tinggi melakukan kebiasaan yang lebih sehat, lebih sedikit mengalami komplikasi kehamilan, lebih baik dalam pengontrolan berat badan dan lebih teratur melakukan perawatan kehamilan dibandingkan dengan ibu dengan status sosial ekonomi yang rendah. Ibu dengan status sosial ekonomi rendah berisiko lebih tinggi terjadi komplikasi kehamilan. Penelitian di India menunjukan kelompok status sosial ekonomi rendah sebanyak $73,58 \%$ mengalami preeklampsia, nilai ini lebih tinggi dibandingkan pada kelompok status ekonomi lebih tinggi yaitu sebesar 48,2\% kasus preeklampsia (Latha, 2013).

Penelitian ini akan menganalisa lebih mendalam tentang faktor risiko pada pasien preeklampsia di Kabupaten Pekalongan. Berdasarkan rumusan masalah tersebut maka pertanyaan penelitian ini adalah 
Jurnal Ilmiah Kesehatan (JIK) Vol X, No. 2, September 2017 ISSN 1978-3167 E-ISSN 2580-135X

"Bagaimana faktor risiko pada pasien preeklampsia di Kabupaten Pekalongan?"

\section{Metode}

Penelitian ini merupakan penelitian deskriptif pada 107 ibu postpartum dengan preeklampsia yang dirawat di rumah sakit Kraton, Kajen dan RSI Muhammadiyah Pekajangan, kabupaten Pekalongan pada tahun 2015.

Uji etik telah disahkan oleh komite etik Fakultas Ilmu Keperawatan Universitas Indonesia. Seluruh ibu postpartum dengan preeklampsia yang sesuai dengan kriteria inklusi diberi penjelasan singkat tentang tujuan penelitian dan diminta persetujuannya dengan menjaga kerahasiaan informasi responden. Selanjutnya, responden mengisi kuesioner yang telah disiapkan dan dikembalikan setelah diisi lengkap. Peneliti selanjutnya memasukan data responden kedalam sistem komputer untuk dianalisis. Metode pengambilan sampel adalah Consecutive Sampling.

Pengambilan data dimulai tanggal 25 Juni sampai 10 Nopember 2015. Analisis data dilakukan pada tanggal 11 Nopember - 20 Nopember 2015.

Alat pengumpulan data pada penelitian ini adalah kuesioner yang terdiri dari kuesioner biodata dan kuesioner status sosial ekonomi menggunakan Kuppuswamy's Socioeconomic Status Scale terdiri dari pendidikan, pekerjaan dan pendapatan (Dudala, 2013). Analisa data yang digunakan dalam penelitian ini adalah dengan analisa univariat menampilkan distribusi frekuensi dan persentase data yang diperoleh.

\section{Hasil}

Berikut ini hasil analisis univariat dari variabel status sosial ekonomi, usia, indeks massa tubuh, paritas, riwayat preeklampsia dan riwayat penyakit dahulu.

Tabel 1

Distribusi Frekuensi

\begin{tabular}{lll}
\hline Variabel & f (n) & $(\%)$ \\
\hline
\end{tabular}

\begin{tabular}{llcc}
$\begin{array}{l}\text { Status Sosial } \\
\text { Ekonomi }\end{array}$ & $\begin{array}{l}\text { kelasmenengah } \\
\text { ke bawah }\end{array}$ & 83 & 77,6 \\
kelasmenengah & 24 & 22,4 \\
Usia Ibu & $>35$ tahun & 24 & 22,4 \\
& $</=35$ tahun & 83 & 77,6 \\
Kegemukan & Gemuk & 61 & 57 \\
& Normal & 46 & 43 \\
Paritas & Primipara & 55 & 51,4 \\
& Multipara & 52 & 48,6 \\
Riwayat & Ada & 5 & 4,7 \\
Preeklampsia & Tidak Ada & 102 & 95,3 \\
Riwayat Penyakit & Ada & 22 & 20,6 \\
Kronis & Tidak ada & 85 & 79,4 \\
\hline
\end{tabular}

Tabel 1 menunjukan hasil responden sebagian lebih banyak memiliki status sosial ekonomi kelas ekonomi menengah ke bawah $(77,6 \%)$. Usia responden mayoritas kurang dari atau sama dengan 35 tahun $(77,6 \%)$ dengan Indeks Massa Tubuh sebanyak 57\% gemuk ringan, dan memiliki anak pertama sebanyak (51,4\%). Responden mayoritas tidak memiliki riwayat preeklampsia sebelumnya $(95,3 \%)$ dan tidak memiliki riwayat penyakit terdahulu sebanyak $79,4 \%$.

Tabel 2

Distribusi Frekuensi Responden Menurut Sosial Ekonomi $(\mathbf{n}=107)$

\begin{tabular}{|c|c|c|c|}
\hline \multicolumn{2}{|c|}{ Karakteristik Responden } & \multirow{2}{*}{$\begin{array}{c}\text { Frekue } \\
\text { nsi (n) }\end{array}$} & \multirow{2}{*}{$\begin{array}{r}\begin{array}{r}\text { Perse } \\
\text { ntase } \\
(\%)\end{array} \\
5,6\end{array}$} \\
\hline $\begin{array}{l}\text { Pendidi } \\
\text { kan }\end{array}$ & $\begin{array}{l}\text { Sarjana, } \\
\text { Pascasarjana }\end{array}$ & & \\
\hline & Diploma & 2 & 1,9 \\
\hline & SMA/MA & 20 & 18,7 \\
\hline & SMP & 43 & 40,2 \\
\hline & SD & 35 & 32,7 \\
\hline & Tidak Sekolah & 1 & 0,9 \\
\hline \multirow[t]{12}{*}{$\begin{array}{l}\text { Pekerj } \\
\text { aan }\end{array}$} & & & \\
\hline & Tenaga Profesional & 4 & 3,7 \\
\hline & Tenaga Semi & 1 & 0,9 \\
\hline & Profesional & & \\
\hline & Tenaga & 2 & 1,9 \\
\hline & $\begin{array}{l}\text { Administrasi, petani, } \\
\text { pemilik toko }\end{array}$ & & \\
\hline & Tenaga Trampil & 9 & 8,4 \\
\hline & Tenaga Semi & 27 & 25,2 \\
\hline & Trampil & & \\
\hline & Tenaga Tidak & 25 & 23,4 \\
\hline & Trampil & & \\
\hline & Tidak bekerja & 39 & 36,4 \\
\hline
\end{tabular}




\begin{tabular}{clcc}
\hline Karakteristik Responden & $\begin{array}{c}\text { Frekue } \\
\text { nsi (n) }\end{array}$ & $\begin{array}{c}\text { Perse } \\
\text { ntase } \\
(\%)\end{array}$ \\
\hline $\begin{array}{c}\text { Pendap } \\
\text { atan }\end{array}$ & $\geq 3.608 .000$ & 1 & 0,9 \\
$\begin{array}{c}\text { Rupia } \\
\text { h) }\end{array}$ & $1.804 .000-$ & 5 & 4,7 \\
& 3.606 .000 & & \\
& $1.353 .000-$ & 15 & 14 \\
& 1.802 .000 & & \\
& $902.000-1.351 .000$ & 21 & 19,6 \\
& $541.000-900.000$ & 44 & 41,1 \\
& $182.000-539.000$ & 16 & 15 \\
& $\leq 180.000$ & 5 & 4,7 \\
\hline
\end{tabular}

Tabel 2 menunjukan bahwa karakteristik ibu menurut kelompok pendidikan mayoritas SMP $(40,2 \%)$, tidak bekerja $(36,4 \%)$, dan memiliki pendapatan antara Rp 541.000 - $900.000(41,1 \%)$.

\section{Pembahasan}

Karakteristik responden pada penelitian ini menggambarkan karakteristik ibu preeklampsia di Kabupaten Pekalongan. Preeklampsia terjadi pada ibu primipara sebanyak $51,4 \%$. Hasil ini sesuai dengan penelitian Nurmalichatun (2013) yang menunjukan bahwa preeklampsia 5\% lebih banyak terjadi pada ibu primipara dibandingkan dengan ibu multipara.

Ibu yang mengalami preeklampsia berusia kurang dari atau sama dengan 35 tahun sebanyak $77,6 \%$. Hal ini sesuai dengan penelitian yang dilakukan oleh Sari \& Sulastri (2007) yang menunjukan bahwa ibu preeklampsia berusia 20-35 tahun sebanyak $67,2 \%$ dan penelitian Yulianti \& Fikawati (2005) yang menunjukan hasil ibu preeklampsia berusia 20-35 tahun sebanyak $77,1 \%$.

Usia ibu pada penelitian ini berkaitan dengan status primipara. Ibu primipara sebagian besar berada pada usia $\leq 35$ tahun sehingga angka preeklampsia tinggi pada usia tersebut. Hal ini disebabkan pada ibu preeklampsia primipara, pembentukan antibodi terhadap antigen plasenta yang tidak sempurna pada kehamilan pertama sehingga ibu akan mengalami preeklampsia dan berisiko mengalami preeklampsia juga di kehamilan selanjutnya.
Jumlah ibu preeklampsia lebih dari setengah adalah gemuk. Data ini sesuai dengan penelitian Aminoto, Karyono, \& Dewi (2013) yang menyatakan bahwa sebanyak $34,4 \%$ responden dengan obesitas mengalami preeklampsia berat. Sebaliknya, pada ibu dengan preeklampsia ringan sebagian dialami oleh ibu dengan kegemukan normal. Kegemukan menggambarkan akumulasi lemak abnormal pada tubuh yang teriadi karena asupan energi yang melebi 47 geluaran kalori. Ibu dengan kegemukan memiliki risiko tinggi mengalami hipertensi kehamilan.

Ibu yang pernah mengalami preeklampsia sebelumnya dan preeklampsia pada kehamilan pertamanya lebih banyak $(56,1 \%)$ daripada ibu yang tidak pernah mengalami preeklampsia dikehamilan sebelumnya.. Penelitian sesuai dengan temuan Hasanah, Siswanto, \& Pranoto (2014) yang menunjukan bahwa proporsi ibu dengan riwayat preeklampsia sebanyak $53 \%$. Hasil penelitian ini menguatkan teori bahwa riwayat preeklampsia pada kehamilan sebelumnya menyumbang $20 \%$ risiko preeklampsia pada kehamilan berikutnya. Hal ini terjadi karena preeklampsia merupakan penyakit yang memiliki risiko kekambuhan.

Ibu preeklampsia yang tidak memiliki riwayat penyakit kronis sebanyak 79,4\%. Angka ini sesuai dengan penelitian Yulianti \& Fikawati (2005) menunjukan bahwa ibu preeklampsia yang tidak memiliki riwayat penyakit kronis sebesar 90,2\%. Hal ini dapat terjadi karena pada ibu dengan riwayat penyakit kronis memiliki tingkat kewaspadaan yang lebih tinggi sehingga lebih peka terhadap kondisi kesehatannya.

Status sosial ekonomi ibu preeklampsia sebagian besar menengah ke bawah. Hal ini sesauai dengan penelitian Sari \& Sulastri (2007) yang menunjukan bahwa sebagian besar ibu preeklampsia berpendidikan SMP. Pekerjaan ibu sebagian besar sebagai ibu rumah tangga. Status sosial menengah ke bawah mengindikasikan pendidikan yang 
Jurnal Ilmiah Kesehatan (JIK) Vol X, No. 2, September 2017 ISSN 1978-3167 E-ISSN 2580-135X rendah dan menyebabkan ibu sulit untuk mendapat pekerjaan sehingga kebanyakan ibu sebagai ibu rumah tangga.

Padahal, apabila Ibu yang bekerja di sektor formal, Ibu akan terakses lebih baik dengan berbagai informasi termasuk informasi kesehatan. Hal ini memungkinkan untuk dapat lebih aktif dalam mengambil keputusan bagi dirinya, termasuk dalam kesehatan. Status kesehatan reproduksi ibu dapat ditingkatkan dengan cara ibu mengetahui dan mengerti hak-hak reproduksinya sehingga ibu mampu memutuskan dan memilih pelayanan kesehatan yang dibutuhkan. (Yulianti \& Fikawati, 2005).

Jenis pekerjaan berisiko preeklampsia. Jenis pekerjaan yang banyak dilakukan oleh ibu preeklampsia di Pekalongan adalah pengolahan industri batik, baik pengolahan batik rumahan ataupun pabrikan. Pengolahan batik rumahan dimulai dengan memotong kain, memproses batik dengan pewarna, menjemur, melipat, menjahit sesuai model pakaian, memasang kancing, dan packing produk batik. Ibu pekerja yang melakukan pemotongan kain, penjahitan, pemasangan kancing, dan packing produk biasanya bekerja dengan duduk lama selama bekerja. Pekerja pabrik batik biasanya membutuhkan proses kerja dengan cara berdiri lama selama waktu kerja karena harus melakukan pemintalan, mengecapan, dan packing produk batik. Pola kerja yang monoton menimbulkan risiko preeklampsia terhadap ibu hamil.

Jenis pekerjaan yang membutuhkan posisi berdiri selama lebih dari satu jam berturutturut tanpa berjalan, pekerjaan yang membutuhkan naik turun tangga, dan bekerja selama 5 hari berturut-turut tanpa berhenti merupakan risiko preeklampsia. Pola kerja dengan berjongkok, berlutut, mendorong, menarik benda, kontak dengan getaran, menuntut kecepatan, kerja yang keras, dan tidak ada pengaturan waktu istirahat yang baik juga berkaitan dengan preeklampsia (Marcoux \& Croteau, 2007)

\section{Kesimpulan}

Hasil penelitian ditemukan pasien preeklampsia berusia kurang dari atau sama dengan 35 tahun, kehamilan anak pertama, mengalami kegemukan dan tidak memiliki riwayat preeklampsia dan penyakit kronis lain sebelumnya. Status sosial ekonomi sebagian besar pada pasien preeklampsia adalah menengah kebawah.

\section{Ucapan Terimakasih}

Terimakasih pada Ketua dan keluarga besar Stikes Muhammadiyah Pekajangan atas semua dukungan yang diberikan sehingga peneliti dapat menyelesaikan studi ini.

\section{Referensi}

Al-Mulhim, A.-A., Adel, A.-H., Fathia, A.J., \& El-Harith, E.-H. (2003). Preeclampsia : maternal risk factors and perinatal outcome. Fetal Diagnosis and Therapy, 18, 275-280. http://doi.org/10.1159/000070809

Aminoto, L. N., Karyono, S. S., \& Dewi, D. (2013). Faktor risiko preeklampsia berat di ruang bersalin RSUD dr. Moh. Soewandhi Surabaya. Jurnal Ilmu Kesehatan, 2, 32-40. http://doi.org/ISSN 2303-1433

Dudala, S. R. (2013). Kuppuswamy's socioeconomic status scale - A revision of economic parameter for 2012.

International Journal of Research \& Development of Health, 1(1), 2-4.

Hasanah, U., Siswanto, Y., \& Pranoto, H.

H. (2014). Faktor-faktor yang

berhubungan dengan kejadian preeklampsia pada ibu hamil di RSUD Ambarawa tahun 2014. STIKes Ngudi Waluyo, 1-7.

Kemenkes. (2014a). Profil Kesehatan

Indonesia Tahun 2013. Jakarta:

Kementrian Kesehatan RI.

Kemenkes. (2014b). Situasi Kesehatan Ibu.

Jakarta: Pusta data dan informasi

Kemenkes RI.

Larrañaga, I., Santa-Marina, L.,

Begiristain, H., Machón, M., Vrijheid,

M., Casas, M., ... Fernandez, M. F.

(2013). Socio-economic inequalities in 
Jurnal Ilmiah Kesehatan (JIK) Vol X, No. 2, September 2017 ISSN 1978-3167 E-ISSN 2580-135X health, habits and self-care during pregnancy in Spain. Maternal and Child Health Journal, 17(7), 1315-24. http://doi.org/10.1007/s10995-0121134-4

Latha, K. (2013). Maternal socioeconomic status and nulliparity : A double fold risk factor for preeclampsia among WHO. (2013). Trend in Maternal Mortality: 1990 to 2013. Genewa, Switzerland: World Health Organization.

Yulianti, L., \& Fikawati, S. (2005). Preeklampsia berat di RSUD Bayu Asih Purwakarta. Jurnal Kesehatan Masyarakat Nasional, 16424(254), 3944. antenatal mothers. Indian Journal of Health and Wellbeing, 4(1), 187-193.

Marcoux, S., \& Croteau, A. (2007).

Population-based study on occupational risk factors for study preeclampsia gestational hypertension. Scandinavian Journal of Work, Environment \& Health, 33(no 4), 304317.

Nurmalichatun. (2013). Hubungan antara primipara dan penyakit diabetes mellitus pada kehamilan dengan kejadian preeklampsia pada ibu hamil di RSUD dr. H. Suwondo, Kendal. STIKes Ngudi Waluyo. Retrieved from http://www.perpusnwu.web.id/karyail miah/documents/3181.pdf.

Pipkin, F. B. (2001). Risk factor for preeclampsia. The New England Journal of Medicine, 344(12), 925-927.

Ruddy, L., \& Kearney, K. (2000). Emergency : Preeclampsia. The American Journal of Nursing, 100(8), $45-46$.

Sari, E., \& Sulastri. (2007). Faktor - faktor yang berhubungan dengan kejadian preeklampsia di rsud dr. moewardi surakarta, 189-198.

Sibai, B. M. (2003). Diagnosis and management of gestasional hypertension and preeclampsia. Obstetrics \& Gynecology, 102(1), 181192. http://doi.org/10.1016/S00297844(03)00475-7

Skjaerven, R., Wilcox, A. J., \& Lie, R. T. (2002). The interval between pregnancies and the risk of preeclampsia. The New England Journal of Medicine, 346(1), 33-8. http://doi.org/10.1056/NEJMoa011379 
Jurnal Ilmiah Kesehatan (JIK) Vol X, No. 2, September 2017 ISSN 1978-3167 E-ISSN 2580$135 X$ 